\title{
The income tax compliance of social media influencers during COVID-19 pandemic: An exploratory study
}

\author{
Yeney Widya Prihatiningtias ${ }^{1 *}$, Gracyella Natalie Putri Karo Karo ${ }^{2}$ \\ ${ }^{1}$ Department of Accounting, Faculty of Economics and Business, Universitas Brawijaya, \\ Malang, Indonesia \\ ${ }^{2}$ Department of Accounting, Faculty of Economics and Business, Universitas Brawijaya, \\ Malang, Indonesia \\ *Corresponding Author(s) Email: yeney.wp@ub.ac.id
}

\begin{abstract}
Social media platforms have been an important source for the dissemination of information, especially during the COVID-19 social restrictions (work from home) mandate. As a result, most companies now rely more on social media influencers to deliver their brand values. However, many of these influencers do not report and pay their income tax from their social media paid activities. This study is the first to understand the reasons behind their tendency behavior to comply and or incompliance income tax in Indonesia during the COVID-19 pandemic. A qualitative method with in-depth interviews, observation, and documentation was used as the method of study. A total of thirteen Indonesian millennials influencers with a minimum number of 10,000 followers and taxable income from social media were involved in the study to share their views about their tax compliances behavior. Our findings revealed that there are indices that affect tax incompliant behavior among millennial social media influencers such as the sufficiency of knowledge about tax, unclear tax imposition and categorization mechanism, the level of trust, nationalism, and administrative needs for works. These finding also implies that there is an urge to educate influencers about tax compliance by using more suitable content and media to maximize the potential tax revenue from this booming profession.
\end{abstract}

Keywords: COVID-19; Tax Compliance; Social Media; Influencers; Millennial

JEL Code:

H21, H26, H30

DOI:

10.31106/jema.v18i2.12789

Article History:

Received 2021-08-14

Reviewed 2021-09-12

Revised 2021-09-30

Accepted 2021-10-10

Licensed:

CC-BY 
The income tax compliance of social media influencers during COVID-19 pandemic: An exploratory study by Yeney Widya Prihatiningtias, Gracyella Natalie Putri Karo Karo

\section{Introduction}

The tax has an essential role as the largest source of state revenue and a tool for the government to drive national economic development. Therefore, the effectiveness of tax payments by the taxpayers, usually specified as tax compliance, is an important contributor to government income. De Neve et al. (2021) define tax compliance as the involvement of both the truthful reporting of taxable income and the timely payment of tax dues. However, there are still many taxpayers who do not understand their tax obligation and some of them intentionally violate tax rules (Tarjo \& Kusumawati, 2006). In the meantime, the COVID-19 pandemic has affected almost all sectors in life, including the tax sector. Unfortunately, taxpayer compliance has always been a problem that until now has not been resolved, especially in the emergence of a new profession called social media influencer (Suciu, 2020; Uly, 2020). Compliance and incompliance are defined as behavior influenced by several aspects such as material, emotional, and normative (Etienne, 2011).

The government around the world has tried to minimize the gap between the expected amount of tax received and the real tax income by understanding the drivers of tax compliance and the most effective way to minimize the cost of doing so (De Neve et al., 2021). This has been a challenging effort, especially during the COVID-19 pandemic. Based on the government revenue and expenses budget, income from the tax sector has experienced a significant decline of $-9.2 \%$ in 2020 compared to previous years which always increased. This may be due to the hardships faced by industries during the pandemic for the last two years so that their ability to pay tax has also decreased. On the other hand, the technology sector has experienced a positive impact especially for the use of social media which has doubled compared to the previous year (Kemp, 2021).

Social media platforms have been an important source for the dissemination of information, especially during the COVID-19 social restrictions (work from home) mandate. As a result, most companies now rely more on social media influencers to deliver their brand values. According to Taylor (2020), 13-18-year-olds are 70\% to 54\% more likely than a year ago to follow a celebrity online (bloggers, vloggers, Instagram, Youtube, and other social media). Furthermore, 58 percent of Gen $\mathrm{Z}$ and 48 percent of Millenials say they've purchased something based on a celebrity's recommendation. Therefore, due to the potential contribution to enhancing the national economy, the risen of the social media influencer profession is taken seriously as the new potential taxpayer. 
Although, the topic of tax compliance determinants is not relatively new for the taxation study (Batrancea et al., 2019; Hofmann et al., 2017; Hunt \& Iyer, 2018), there are a few studies that explored the emerging jobs like social media influencers in the taxation study comprehensively. Anggadha \& Rosdiana (2020) and Roria \& Sari (2021), which analyzed the imposition of tax and optimizing tax solutions for endorsement activities by social media influencers in Indonesia, found that the treatment of income tax on endorsement activities of social media influencers can be carried out with several collection techniques following the conditions in which each endorsement activity is grouped as a tax object and payable VAT (Value-Added Tax) so that the local government can increases their national incomes to fill social welfare (Falya \& Dirkareshza, 2021). In addition, a detailed study was held by Radvan (2021) who argues that rather than create narration about how to increase the compliance of the influencers, the tax authorities should learn the finest way to impose a tax on influencers by focusing on the content of the relationship generating influencers' income so that the government may finally able to calculate the best amount of tax should be paid. Groulx \& McGregor (2018) and Sekeroglu \& Bilgin (2019) also do the same thing in seeing a design to integrate social media data into the tax analytics process to detect tax evasion by influencers and promote tax enforcement activities, and to provide tax regulations in such a way to fit the government needs with the ability of influencers to pay tax.

Thus, this current study tries to mix what previous researchers have done on the topic of influencers and tax by exploring other factors which may originate from the internal perspectives of influencers to comply in paying tax, as well as to see the perspectives of the government of Indonesia in terms of the efforts have done so far in imposing a tax to influencers. This may balance the point of view of the compliance itself since the focus is not only on the side of the taxpayers or the influencers but also from the tax authority who has the responsibility to socialize the tax regulation as well as to ensure the best way to impose it to the taxpayers. This study is also held during the COVID-19 pandemic when the number of influencers has risen significantly, so that the results may indicate whether the government revenue from income tax from the influencers has also increased. A case study method was applied to gather data from Indonesian social media influencers, dominantly Instagram, regarding their compliant decisions. Online interviews were also conducted with a tax officer to validate the information had been collected from the informants. The paper continues with a literature review, method, results, and discussion as well as conclusion and suggestions for future research. 
The income tax compliance of social media influencers during COVID-19 pandemic: An exploratory study by Yeney Widya Prihatiningtias, Gracyella Natalie Putri Karo Karo

\section{Literature Review}

\section{Tax Regulations in Indonesia}

Tax is the largest contributor to state revenue to improve welfare and national development, as stated in article 1 UU KUP (Andreas \& Savitri, 2015). Therefore, taxpayer compliance in paying tax is very important. Tax revenue is very influential for a country's development which is why tax compliance must have strived. Efforts to increase tax compliance can be carried out by extensification and intensification of tax by the addition of tax subjects and objects through various socializations (Nugroho et al., 2016). The obligation to pay tax by the citizens is a tangible manifestation of obedience to the law.

There are many types of tax, one of which is income tax. Income tax is a tax imposed on a tax subject who receives or earns income during a tax year or income in part of a taxable year if the tax obligations objectively begin or end in the tax year. The subject of income tax according to Law No 36 of 2008 is divided into two, namely, first, the subject of domestic income tax. It is the income of a domestic individual who is an Indonesian citizen or foreigner who works and earns income and is domiciled (permanently) in Indonesia for more than 183 days within 12 months, or who in one tax year is in Indonesia and has the intention to stay in Indonesia; except for a taxpayer who receives income below the non-taxable income of IDR 54,000,000 annually is not required to pay income tax. Second, foreign income tax subject, who is a foreign individual income tax subject that is not domiciled and stays less than 183 days in Indonesia within 12 months. Regarding, the recent trends of social media technologies, The Minister of Finance of the Republic of Indonesia, Sri Mulyani, clearly stated that social media influencers (from various social media platforms) are obligated to pay tax routinely. As it is regulated on law number 210/PMK.010/2018 which refers to the tax treatment of transactions made through social media platforms that are also applied to social media influencers (Nurhaliza, 2020). An influencer is categorized as an art worker and obligated to report and pay income tax as regulated in law 36 of 2008.

\section{Tax Compliance}

Compliance and incompliance are complex forms of behavior that are caused by various factors which are the combination of material, emotional, and normative goals (Etienne, 2011). Some experts argue that compliance behavior is grouped into "planned" behavior and "automatic" behavior. Automatic behavior is defined as the product of habits and routines, while planned compliance and disobedience are carried out intentionally for various purposes 
and reasons (Etienne, 2011). Tax compliance in Indonesia has been a classic issue that has not been fully addressed (Mutia, 2014), which is defined as the ability and willingness of taxpayers to comply with tax laws determined by ethical, legal environment, and other situational factors at a certain time in a certain place.

Tax compliance can also be described as a voluntary action in reporting and paying tax, and the taxpayer does not have to wait for follow-up from the tax authorities (Singh \& Bhupalan, 2001). Tax knowledge is necessary for determining taxpayer compliance behavior and can be divided into two aspects, namely general and formal knowledge (Palil, 2010). Tax compliance is also defined as fulfilling all tax obligations and rights of taxpayers following tax laws and regulations and can be divided into two, namely formal tax compliance, which directs taxpayers to comply with tax laws and regulations, and material tax compliance, which is a condition where the taxpayer substantially complies with all material tax provisions.

Moreover, Taing \& Chang (2021) use the Theory of Planned Behavior (TPB) to understand the behavior of Phnom Penh's citizens in complying with their tax obligation and find that tax morale, tax fairness, and tax complexity have influenced the intention to pay tax. Le \& Moore (2021) also use TPB to analyze the electronic tax compliance of small and medium enterprises (SMEs) in Vietnam and find that the most influencing factor to increase tax compliance is taxpayer awareness. The Vietnamese government should pay attention to promoting and supporting SMEs to raise their tax obligation awareness. Owusu et al., (2021) also confirm a similar research result that taxpayers would not comply if the tax rate is assumed to be too high and the tax authority cannot be trusted. The study also finds that the perceived tax complexity, antecedent-based intervention strategies, attitude, subjective norms, and moral obligation are believed to increase tax compliance intention. Besides, the use of advanced computer technology in the tax payment system is also argued to improve tax compliance among African business owners (Mascagni et al., 2021). On the contrary, new technologies for implementing tax regulations and clear tax regulations are the lowest factor influencing Iranian football players' tax compliance (Memari et al., 2021).

In the meantime, in the context of small and medium enterprises in Indonesia, Novikasari et al. (2021) show that the reduction of the final income tax tariff from $1 \%$ to $0.5 \%$ and the existence of legal certainty regarding the taxation time frame have a positive impact on tax compliance. Indonesia applies a self-assessment system in tax reporting. The self-assessment system is where taxpayers calculate, deposit, and report taxes owned voluntarily. The tax officials only supervise through a series of monitoring and law enforcement actions. The 
The income tax compliance of social media influencers during COVID-19 pandemic: An exploratory study by Yeney Widya Prihatiningtias, Gracyella Natalie Putri Karo Karo

application of the self-assessment system to tax reporting carries a risk where taxpayer judgment relies on the temptation to rely on tougher law enforcement regimes (James \& Alley, 2002). According to the website of government tax officials, one of the keys to tax compliance is the ease of paying taxes. The facilities that have been implemented in Indonesia include improving the electronic payment system, combining several types of taxes or even removing the irrelevant tax, and simplifying the taxpayer reporting process. Such increased convenience is expected to raise public awareness in paying taxes.

\section{Social Media Influencers and Tax Obligation}

Social media has become one of the most important communication tools, which is an application built on an internet base that allows the creation and exchange of user-generated content (Kaplan \& Haenlein, 2010). Social media is also defined as a technology that allows users to communicate, create and share content through a virtual community or social networks such as Instagram, Youtube, and Tiktok. The use of these social media applications has increased drastically since the COVID-19 pandemic because people may enjoy entertainment as well as receive current news or information during the quarantine, lockdown, and limitation of outside activities (Hussain, 2020; Wiederhold, 2020). Social media has changed the way of consumers interact with the brand. The trend of using social media to promote products is a significant shift in the marketing sector. Many businesses used social media (influencers) to disseminate their promotional efforts (Ardiansyah \& Sarwoko, 2020; Enyioko \& Okwandu, 2019). Social media influencers on Instagram, Youtube, and Tiktok, also known as digital opinion leaders because they can mediate and influence communities in the digital environment, where messages can be disseminated quickly and easily with potential viral effects (Uzunoğlu \& Misci Kip, 2014).

The connection between social media influencers and tax is based on the income that influencers receive through marketing services they provide on social media. Every social media platform offers various types of features for its users. Instagram has a variety of features, one of which is a promotion feature. This feature applies a conversion system for regular posts on Instagram into a paid one where the Instagram algorithm will provide higher outreach and engagement which works best for boosting the influencer's account or branding awareness and visibility. This feature is independently selected by account owners who wish to promote their account and get more people to follow into their account. The fee rate charged may vary depending on the type of engagement, location, duration, and the targeted outreach, which will then be taxed at $10 \%$. 
In addition to the marketing scheme held on social media, there are other types of marketing activities carried out by individuals that have been identified or provided by Instagram. The intended individual is an influencer on social media platforms. The types of transaction and marketing procedures carried out by influencers are also varying and quite complex. When social media audiences see influencers on platforms such as Instagram, Facebook, Twitter and then the audience may check on the influencers' shows when expressing their preference toward a brand's product or service. Later, the audience may check the brand and get interested. This is an example of influencer marketing. Influencers provided a service by reviewing, liking, and commenting on particular products.

Influencers also have the potential to provide feedback to brand partners in form of exposure, potential customer, and brand awareness to their followers. This procedure will create income for influencers from the payment toward their marketing services (endorsement, paid promote and so on). The income generated by influencers varies and there is no standard and limit to the fee charged for influencers' service. The rates charged by influencers may vary, starting from IDR 500,000 to millions of rupiah. The income earned by influencers results in the influencer's obligation to pay tax as long as the income has exceeded the amount of non-taxable income. Influencers are subject to income tax on transactions made for services provided by influencers on social media. Instagram classifies user accounts into accounts for content creators and brands.

Meanwhile, personal accounts and business accounts are distinguished based on the insight features on their social media accounts. However, in a business account, there is still no liability from the content creator's account about taxation toward their commercial activities although they have been regulated to pay income tax. The reason is that it is still difficult to identify and count influencer commercial activities in detail as some of the information is confidential. Unlike Instagram influencers, Youtubers generate income from the number of views on their videos or fee per mile after they monetize their account where Google can advertise a contracted advertiser on Youtuber's video. The income, called fee per miles, will be performed through Google AdSense. However, for Instagram, there is still no rigid measurement to be imposed of tax as it is hard to distinguish between paid posts and updated posts that contain promotional elements. Therefore, Instagram influencers need to have their voluntary sense of reporting their true and honest income from social media activities as one of the Indonesian citizen obligations. 
The income tax compliance of social media influencers during COVID-19 pandemic: An exploratory study by Yeney Widya Prihatiningtias, Gracyella Natalie Putri Karo Karo

\section{Methods}

This study employed a qualitative or inductive method which starts from a specific to a more general discussion. The use of the inductive method in this study makes it easier to analyze the relationship of each aspect under the qualitative method. Qualitative research is used to explore and explain a phenomenon or problem completely and thoroughly with the orientation that the research result can have a positive impact on the world by empowering the experience of a group of individuals towards a phenomenon (Creswell, 2007). This method produces non-numeric and descriptive data (Sekaran \& Bougie, 2019). In addition, the use of the qualitative method also aims to gain a general understanding of the phenomena faced by the informants, which will later be drawn from general conclusions to specific conclusions. The method used in this study is a case study that focuses on gathering information and empirically investigating the object of contemporary events or phenomena in in-dept and specifically in real-life contexts (Yin, 2012). The basis for the consideration of the researcher using the case study method is because the study aims to find out strategically selected cases in naturalistic settings that allow a researcher to directly and deeply study the issues (Piekkari et al., 2009).

Table 1. Interview Protocol

\section{Questions related to the informants' tax compliance or incompliance}

Do you know that influencers have to report and pay tax?

Do you report your income tax?

What do you think about Indonesia's tax system for social media influencers?

What are the reasons for your compliance or incompliance in reporting your income tax?

Questions related to the effect of the COVID-19 pandemic on the informants occupation

What are the differences between being an influencer before and after the COVID-19 pandemic?

Does the COVID-19 pandemic affect your compliance with reporting income tax?

How is your social media account progressing before and after the COVID-19 pandemic?

Have you experienced an increase in income since the COVID-19 pandemic?

What kind of products do you often promote before and after the COVID-19 pandemic?

Primary data was collected directly from Instagram influencers that meet certain criteria such as Indonesian citizens domiciled in Indonesia, active social media users, have a 
minimum number of 10,000 followers on their personal Instagram account or other social media platforms and received material returns such as freebies or money minimum IDR 500,000 to each provision of services they provide in the form of advertisement/ promotions/ endorsement or paid promotion. Unstructured interview technique was used to get the data from thirteen influencers from five different regions in Indonesia. Interviews were conducted through video conference and telephone. The interview protocol used during the data collection is as described in Table 1.

Data analysis strategy was carried out through three streams of data processing activities simultaneously, namely data reduction, data display, and conclusion drawing and verification (Miles \& Huberman, 1994). The data obtained from informants have to be credible and comprehensive. Thus, triangulation was employed to obtain the validity of this study. Triangulation has been proven and widely accepted to be an effective tool in achieving a level of validity or confidence and to improve the analysis and interpretation of findings in a study (Beverland \& Lindgreen, 2010; Yin, 2012). To do so, an interview with the tax officer was conducted to validate and synchronize the findings and reality of the result.

\section{Result and Discussion}

A total of thirteen informants have taken part in this study, namely VS, NK, TT, GK, NT, RK, IK, AN, JA, SR, OP, YT, and NC. Their names are abbreviated for privacy. The informants comprised of ten females and three males with the age range of 18-25 years, from five different regions in Indonesia. Most of the influencers on this study have an account on more than one social media application other than Instagram, such as TikTok, YouTube, and Twitter. The interviews were conducted with those who met the criteria as an influencer. The informants live in several cities in Indonesia namely, Medan, Surabaya, Jakarta, Bandung, and Jogjakarta. The interview process was carried out separately, one by one, virtually through Zoom, Google Meet, and telephone. From the results of interviews conducted with informants, Instagram is classified as the most social media platform usages for paid promotion and endorsement. Paid promotion is an activity where influencers have to promote a product or service from a brand which influencers have to mention the brand on their social media account without receiving any product in their hand. The partnered brand also has to pay for these services based on the rate requested by an influencer. Not so different with paid promotion, endorsement lies in the product being sent to an influencer to be reviewed or promoted based on their perspective. Even so, each influencer has their own opinion and taste in choosing the types of goods to promote. The promotional activities are subject to varying 
The income tax compliance of social media influencers during COVID-19 pandemic: An exploratory study by Yeney Widya Prihatiningtias, Gracyella Natalie Putri Karo Karo

rates. Each influencer has a different rate depending on their respective desires when promoting a product. Based on the interview's results, paid promotion rates ranged from IDR 500,000 to Millions. Other commercial activities that influencer got paid for include sponsored posts and blogs, digital products, selling ad and editorial space, and webinars and podcast.

\section{Reason for Incompliance}

There are ten of thirteen informants were classified as tax incompliant. During the interview, informants gave various reasons behind their tax-incompliant behavior. Most of them agree that the insufficient and lack of understanding about taxation is the main causes of their incompliances.

"I didn't know that this profession (influencers) would be taxed." (JA)

"I haven't been an influencer that long, so I also just found that I supposed to pay tax." (RK)

"To be honest, I've never heard about income tax imposed on my profession, I thought it only applies for official workers since I consider this job (influencers) as a freelance." (AN)

Based on the interview result with YT on April 10th, 2021, through telephone, He stated that the difference in a generation become a reason for his incompliance behavior.

"As a millennial generation, I have not heard about taxation charge to influencer until I discussed this with my fellows." (YT)

Therefore, OP suggests that to encourage tax compliances behavior and awareness of the young generation, the tax education should be narrated in a "millennial way"

"...people nowadays, especially millennials like me, get info from TikTok, and I haven't seen any tax education on the platform." (OP)

Based on the informants' statement, influencers tend to have insufficient knowledge and a lack of understanding of the tax imposition for the influencer profession. Few informants mentioned their knowledge of legal aspects of the income tax system. It is because they have little or/and they do not consider it important.

"I don't have any knowledge about the legality of tax and the tax itself whatsoever... I think it is not important to think about tax and the system." (NK, TT, GK, NT, IK, and SR) 
One of the aspects that consider as the root causes of the low level of tax compliance is the low awareness and knowledge about taxation. According to Nugroho et al. (2016), taxpayer awareness of the tax function as state financing is needed to improve tax compliance. This profession is considered a new type of job and still needed an extension process due to the wide age range. Thus, equitable distribution of tax information is needed to support influencers' understanding of the importance of paying income taxes in a more targeted manner. Acknowledging this issue, the government should start to consider utilizing eminent online platforms or social media to distribute news, awareness, and education related to tax with Millennials as the targeted audience (Risdiana et al., 2020).

The second is a low level of trust in the taxation system. Following are statements conveyed by informants regarding their incompliance behavior toward the tax system.

"...based on my income, I know that should've paid tax since my income exceeds, but I still don't trust the tax system. I haven't been chased and billed by a tax official, so for now, there's no reason to report either." (VS)

"I still do not have the intention (to pay taxes). Also, I am afraid authorities will charge a large amount of tax..." (YT)

The low level of trust in the tax system implemented to influencer's tax law causes the premise that it is considered avoidable. However, this action is regulated in law and subject to sanctions. The level of trust is a subjective aspect and is considered an influential factor to taxpayer compliance (Faizal et al., 2017). Trust is defined as a positive expectation or hopes that others will not do through words, actions, and policies to act opportunistically. Trust in this study is defined as how individuals perceive that Indonesia's tax system can be trusted or not. Based on the slippery slope model theory, social psychology variables, and deterrence affect the level of voluntary tax compliance (Kirchler et al., 2008). If individuals trust legal policies, the taxpayer's desire to comply will increase (Batrancea et al., 2019). Williams (2020) also mentions that the likelihood of participating in tax-incompliant is mostly associated with the level of vertical (government) and horizontal (others) trust. The lower the trust, the higher the incompliance level.

On the other hand, if an individual's trust toward the system is low, the taxpayer will maximize utility and avoid tax resulting in low levels of compliance (Faizal et al., 2017). Therefore, it is necessary to have a good relationship between the parties involved. Based on the data collection, there is a common threat that informants claimed to have low trust in the tax system because there is still no good relationship between tax authorities and taxpayers so 
The income tax compliance of social media influencers during COVID-19 pandemic: An exploratory study by Yeney Widya Prihatiningtias, Gracyella Natalie Putri Karo Karo

that it gives space for influencers to discourage their intention to report their income tax deliberately. Considering that nowadays the largest tax contributors are Millennials and Generation X, tax officials or governments must build trust by showing a good attitude to taxpayers to maintain good relationships and perceptions (Tjondro et al., 2019).

The third is unclear tax imposition and categorizing mechanism. On April 1st, 2019, the Indonesian Minister of Finance officially issued regulation number 210/PMK.010/2018 concerning tax treatment of trade transactions through the electronic system. Influencers are categorized as service providers. A service provider is an individual, entity, or permanent establishment that resides, is domiciled, or has business activities in the customs area that conducts transactions with service recipients using the platform facilities provided by the marketplace platform provider.

On the other hand, social media such as Instagram is categorized as an electronic platform. An electronic platform is a space in the form of applications, websites, and/or other internet-based content services used for transactions and/or trading facilities through an electronic system or e-commerce (Punardi, 2019). The informants in this study are famous people with different specializations and characteristics. Although influencers are categorized as art workers, there is no clear procedure for imposing and collecting tax toward influencers' income from commercial activity on social media. Similar to other professions, an influencer has multiple types of fields, although they provide similar services. Informants in this study have various types of specialties and trademarks in promoting their service.

Informants with the initials of NT, NK, TT, JA, and JA are influencers in the beauty, fashion, and lifestyle products. Others, with initials of VT, OP, and YT focus on comedy or pranked content. The rest, with initials of SR, IK, and NC specialized in providing educational content about stock and financial matters. This diversity becomes one of the reasons for informants claiming there is no absolute categorization toward influencer's field, and it has caused the absence of compliance behavior on paying income tax, as included in the following statement.

"I discussed with a fellow friend (influencers), and it turned out that some of them in the same field got the same job offer but got billed with a different amount of tax. Thus, it makes me question how the tax system is imposed. Moreover, I don't think the government has specified tax regulation for social media activity such as endorsement or paid promotion on social media either." (NC) 
Based on the statement above, there are differences in the imposition of tax toward tax subjects who pursue the same field as an influencer. This urges influencers' be incompliant because the tax mechanism produces different outcomes due to unclear categorizations of social media activity that will be charged. German experimental studies explain that tax avoidance is positively related to income earned (Kemme et al., 2020; Nguyen et al., 2020). The greater the amount of income earned by influencers, the less desire they are willing to report their tax because they are afraid, they will be taxed a large sum amount. Indeed, no specific policy about influencer activities makes it difficult to determine the amount of tax on their income (Pradana, 2020). According to the Directorate General of Taxes official website, income tax is charged to art workers in two categories, namely agent or artist management, which if the users endorse a subject (influencers) with using an agent or third parties' services, income tax article 23 will be imposed. The other one is independent art workers, which means subjects (influencers) make direct contact (without intermediaries) with their clients or users, who will be imposed income tax article 21.

Apart from the classification above, there is still no specific tax regulation devoted to influencers regarding their specific field and commercial activities. The work of influencers as content creators requires them to continue to innovate. Therefore, a clear legal grounding for influencers in social media platforms is considered crucial, just like any other profession. Unlike Instagram influencers, YouTuber income tax is measurable by calculating their income based on miles per ad-sense. At the same time, influencer on Instagram does not have a definite unit of measurement yet. Therefore, there is a need for regulations that compile the categorization of the types of influencers based on their particular services on social media to minimize the influencers' ignorance and excuse of not paying income tax as required as Indonesian.

\section{Reason for Compliance}

Despite all the incompliance reasons mentioned before, the study found that some influencers already reported and pay their income tax. Aside from their obligation as an Indonesia citizen, three out of thirteen informants who claimed fulfilled their obligations have explained their motives. First, they are having more understanding about tax so that they have more adequate technical knowledge about taxation in which leads to their awareness to pay tax. Information about tax education nowadays is easy to gather. Tax education and socialization is an advanced investment for future benefit to increase the awareness of potential taxpayers in paying taxes especially due to the possibility for a professional such as 
The income tax compliance of social media influencers during COVID-19 pandemic: An exploratory study by Yeney Widya Prihatiningtias, Gracyella Natalie Putri Karo Karo

the influencers (Andreas \& Savitri, 2015). All conveniences to tax information can be obtained by visiting the nearest tax office and directly interacting or consulting both online and offline. Consulting services are usually handled by tax oversight and consulting departments. Moreover, one of them even shares their 'heroic' moments to do tax obligation into their social media account. Publishing their tax fulfillment experience is one of the forms of awareness and supportive gestures to encourage their fellow influencers who may not or are reluctant of the importance of taxation.

"...my income as an influencer is uncertain and volatile. However, I have learned that the amount of the earnings are positively correlated with the tax that will be charged, which means if my income decreases, so do my taxes bill. I did my research about taxation when I first got an email notification regarding my tax bill." (IK)

The second is a high sense of nationalism. According to a statement by one of the informants who compliant with income tax, their compliance behavior with tax is influenced by their nationalism and sensitivity toward the national development, especially in an emerging country like Indonesia.

"We might not receive immediate feedback when paying taxes. However, as I paid my first bill, somehow, I felt like my duty as a citizen was complete, although the amount charged wasn't small." (TT)

"...paying tax is our obligation as Indonesian citizens. Since high school, I've learned that by paying tax, we have already contributed to developing our country." (IK)

Tax education needs to be delivered from an early age, both in the social and educational institutions, intending to cultivate and build awareness of the importance of paying tax. Developing a sense of nationalism will positively build awareness of taxpayers to actively participate in development carried out by the government for the public benefit (Krisna, 2020). As an Indonesian citizen, the obligation to pay tax is a form of compliance with the law. Sensitivity and a high sense of nationalism formed from habits, a love for the nation, and responsibility as a good citizen can increase taxpayer compliance on reporting income tax.

The third is administrative needs for work. Another reason affecting influencers' compliance is their needs related to work requirements. Owning a personal bank account is primary since the service provided is done virtually and usually paid electronically, especially for influencers who take this profession as their main job. Thus, influencers have to carry some documents to be able to run their job smoothly as their job involved various parties to 
work. The process of making a personal bank becomes one of the elements of influencer compliance toward tax obligation. One informant admitted that he/she complies due to the needs of administrative matters which required a Taxpayer Identification Number (TIN).

"I was making a business bank account and required to own a Taxpayer Identification Number (TIN)"; "when I was first billed, I paid a large sum money, but now I learned and used professionals to arrange my taxes." (NK)

“...it was when I made my Taxpayer Identification Number (TIN) for work purposes which later I got a notification email from the tax authorities." (IK)

The reasons given by the informant are unintentionally subjective and not caused by external factors, which then lead to tax. The needs of administrative documents such as Taxpayer Identification Number (TIN) can be an effective tool, especially for tax authorities to identify potential taxpayers (influencers). When an individual already has a TIN, it means that a tax report must be made every year, which consists of the amount of income earned during the year and the calculation of tax that should be paid. This method, which is utilize TIN as a requirement to process administrative matters, has proven effective in influencing taxpayers' thoughts, which later directly affect their compliance. Informants also admitted that they hire professionals or consultants to help them in managing their tax payments.

\section{The Effect of COVID-19 Pandemic}

Five out of thirteen informants declared that they are relatively new to the business and had just started the profession only when the COVID -19 occurs. Those informants began to receive exposure during the pandemic and gained a significant increase of followers on their accounts. The informants begin to accept job offers to review and promote products on their social media account as they reach a certain number of followers, which is considered as prominent to be called an "Influencer." Out of those five informants, others have said that they had been carried this profession long before the COVID-19 pandemic. However, the pandemic increases their account traffic and received more job offers as some brands started to use social media platforms to sell their products due to the effect of Large-Scale Social Restrictions or lockdown which made business owners depend on online selling. The informants mentioned that:

"I often did endorsement and paid promotion, but I received more offers and have packed promotion stories during the pandemic. I also discovered a new brand that launched and opened because of the COVID-19." (NK) 
The income tax compliance of social media influencers during COVID-19 pandemic: An exploratory study by Yeney Widya Prihatiningtias, Gracyella Natalie Putri Karo Karo

“...started this (Instagram) account on 2019, but wasn't that intense and gained double followers to as much as 20.000 new followers during the pandemic." (JA)

"...my post went viral in 2020, which when pandemic first started and I started to gain more followers and receive an endorsement." (GK)

According to the informants' statements above, the COVID-19 pandemic has a positive effect on social media users as well as social media influencers. In addition, the emerging of new influencers is driven by offers from brands produced during the pandemic. VS and AN have confirmed this matter since they promote several brands of medical face masks.

"I promote many brands of face masks during the pandemic." (VS and AN)

While SR, YT, and OP were very happy to promote some brands and types of hand sanitizers that they never knew before.

"This is the first time for me to promote hand sanitizers." (OP)

"This pandemic situation is a blessed for me because many health products need promotion, including hand sanitizers.” (SR)

"I hope stays longer so that I can promote sterilizers and hand sanitizers. Hahaha... no... just kidding... “( (YT)

Through this time, most of the activities are carried out at home using online platforms. Therefore, business owners considered this period is effective to sell products by utilizing social media. Most of the informants experience a massive increase due to several reasons. Firstly, most of the advertisements are dominated by influencers instead of traditional advertisements. Second, the increase in e-commerce users by $154 \%$ shows that consumers rely on social media when searching for products. It emerges the influencers demand to depend on influencer reviews and impressions toward the products. Third, there is an explosion of demand for useful content, especially educational content, self-care, homeworkout, and other activities at home. This situation is beneficial for influencers as a social link between brands and potential consumers who are vital amid social restrictions.

\section{Tax Officer Feedbacks}

Income tax is a tax withheld on income in the form of salaries, wages, honorariums, allowances, and other forms of payments related to work, services, or activities carried out by individual domestic taxpayers. According to Law No 36 of 2008 mentioned previously, influencers who carried out commercial activities on social media can be identified as tax subjects and are required to pay income tax if their income exceeds IDR 54,000,000 annually. 
To support the data comprehensiveness, a tax official in the Indonesian Directorate General of Taxes is involved in this study. The interview was conducted to have a comparison between influencers' responses and tax authorities with regards to the influencer's compliance and incompliant behavior in paying income tax. Tax authorities' statements are also used to support the validity of the data to present research results on this study (Patton, 1999). Several similarities are found between the results of interviews with tax officers and influencers. According to him, the number of tax subjects (influencers) who comply in reporting their tax obligation is still few compared to those who do not comply. He explained that the number of influencers that reported their tax was only a few. However, although the number of influencers who comply is relatively small, the contribution is quite significant. The nominal distribution for commercial activities obtained as influencers is relatively large. In addition, the number of taxpayers who do not report their taxes is considerably large compared to the list owned by the Directorate General of Taxes (DGT). Those taxpayers' data are obtained from a system called the DGT information system. This application contains a taxpayer dataset that is used to facilitate tax officers to find prospective taxpayers by integrating various communication systems, which will later be distributed to each tax office across Indonesia. Currently, DGT is also developing this system to be able to analyze potential social media subjects such as influencers, so that tax officers can observe taxpayers in detail. The efforts that have been done by DGT here are in line with the explanation by Anggadha \& Rosdiana (2020).

He added that regarding the number of obedient tax subjects that is considerably small, influencer's compliance behavior may be influenced by several factors as mentioned by the tax officer below:

“...they have received tax education from schools, teachers, parents, managers, friends, and others."

“...some of them need Taxpayer Identification Number (TIN) for administrative purposes for their work, especially financial matters such as opening bank accounts, deposits, securities, and others."

“...some taxpayers end up reporting their tax because they are often approached by tax officers."

Therefore, it can be concluded that there are several reasons behind influencers' compliance with tax reporting. One of them is sufficient knowledge about tax education, which is an obligation as a citizen, and their sensitivity to the importance of paying taxes from income 
The income tax compliance of social media influencers during COVID-19 pandemic: An exploratory study by Yeney Widya Prihatiningtias, Gracyella Natalie Putri Karo Karo

they earn from social media activities. Besides that, external factors such as urgencies of administrative documents such as Taxpayer Identification Number (TIN) to support their job also become crucial aspects of influencer's compliance behavior. Moreover, intense pressure and visits by tax officials to carry evidence toward taxpayer obligations become one of the most common processes to reach taxpayers although the procedure is considered ineffective.

In addition to the reason for influencers' compliance behavior, the informants also mentioned several statements regarding influencers' incompliance to report income tax such as lack of sensitivity and ignorance about the profession as influencers. As stated by the tax officer, awareness and a direct approach to influencers are necessary to be carried out. Tax officers explain that they are using an approach method to reach out to taxpayers. The method is called the triggering method. A triggering method is an approach in which the tax officer asks for direct interaction to obtain tax payer's recognition of the assets/wealth or income obtained, which will then be compared with the dataset. Other than taxpayer insensitivity toward taxes, social psychology such as trust level on both the tax system and tax authorities influenced taxpayer incompliant behavior. As mentioned previously, tax officer has applied the triggering method to attract more obedient taxpayers. Some of the taxpayers refuse to acknowledge their wealth from the data-informed by taxpayers (Kemme et al., 2020). The reason is that the distrust of tax authorities causes the taxpayer to tend to cover up income and become reluctant to pay tax.

\section{Discussions}

After conducting interviews with thirteen informants, several reasons for compliance and incompliant behavior of influencers in reporting and paying income tax during the COVID19 pandemic are found. The following are the reasons concluded based on the statements mentioned by ten out of thirteen non-compliant influencers regarding paying income tax. First is insufficient knowledge about tax (Hajawiyah et al., 2021). Five out of ten informants explained that the lack of knowledge and understanding about taxation causes an incompliance behavior in paying tax. According to Law No 17 of 2003, tax revenue is one of the sources of state income, which must be able to meet the needs of government administration.

One of the indicators to measure tax revenue is called the tax ratio. The tax ratio relies on three conditions, namely economic situation, tax policies, and administrative capacity. The tax ratio shows the government's ability to collect tax revenue. The higher the tax revenue of the country, the greater the tax ratio will be. Indonesia's tax ratio is at $10.3 \%$ and continues to 
decline sharply in 2020 due to the COVID-19 pandemic. The position of Indonesia's tax ratio is below the standard as a developing country. Taxpayer compliance in paying taxes for state income is positively related to the tax ratio, which shows that taxpayer compliance is still relatively low. One of the reasons is due to inadequate technical knowledge which eventually forced taxpayers to seek the help of professionals.

Lack of technical knowledge among influencers causes unintentional incompliant behavior. Insufficient knowledge and absence of awareness of taxation to influencers also become obstacles to the implementation of the self-assessment system in Indonesia. Insufficient knowledge of taxation causes the taxpayer to be reluctant to contribute to paying taxes (Wardani \& Wati, 2018). Therefore, it is necessary to provide tax education for influencers on social media, especially during the pandemic, which may be conducted with the assistance of technology. Authorities may also use social media as a platform to educate the public and reach potential taxpayers to increase their knowledge about taxation. Taxation approaches and education need to be directed, especially for the millennial generation, whose presence and influence have increased significantly during the COVID-19 pandemic (Sari, 2019).

Second is the low trust level in the tax system. Taxpayers' trust affects tax compliance which is applied in a self-assessment system (voluntary). The sense of trust rests on a good relationship between taxpayers and tax authorities (Faizal et al., 2017). The level of compliance will be at its maximum level when the power and trust of the tax authorities are high. Thus, the low level of awareness of influencers is caused by low trust in the system and relationship with tax authorities. Therefore, building a good relationship among taxpayers and tax authorities is a great foundation to produce awareness to be compliant and lower the possibility of taxpayers' tendency not to comply with their obligation to pay income tax. Building influencers' trust in the tax system is also necessary to create an honest and cooperative behavior, especially for an influencer to follow income tax charged from their earnings received through commercial activities on social media account.

The third is unclear tax imposition and mechanism in categorizing activities. The mechanism is crucial in regulating the process of implementing a policy. The lack of clarity on an enforcement system will result in unwanted actions (Novikasari et al., 2021). Indonesia still has not specifically classified the types of influencer activities on tax regulations. The profession as an influencer has currently categorized as an art worker instead. Other than that, diversification is needed since the social media industry by influencers is a massive business. 
The income tax compliance of social media influencers during COVID-19 pandemic: An exploratory study by Yeney Widya Prihatiningtias, Gracyella Natalie Putri Karo Karo

Likewise, the unclear mechanism imposed on the activity of influencers has resulted in incompliance tax behavior. Thus, specific and targeted categorization is needed to make it easier for taxpayers to understand their obligation to pay income tax. In the United Kingdom, the government has set a detailed tax regulation describing the imposition of tax charges for influencers which are based on the type of activity carried out on social media. Therefore, it is necessary to create a legal procedure that contains special regulations regarding the category of imposition on influencer income.

Among the thirteen informants, only three complied in paying income tax. Their compliance is based on several reasons as follows. First is sufficient knowledge about tax. Public awareness is strongly supported by the education they get from information conveyed in their society, tax authorities, or obtained directly by the taxpayer through personal research (Palil, 2010). If every taxpayer has high awareness and compliance, then the tax revenue will be optimal, and its effect on state revenue will also be greater. Furthermore, according to Alshira'h et al. (2021), tax knowledge has a moderating role in the association between socioeconomic factors and tax compliance. The second is a high sense of nationalism. A high sense of nationalism and concern for the nations positively affect individual taxpayer compliance behavior (Krisna, 2020). Alshira'h et al. (2021) also believe that patriotism and public governance increase and improve tax compliance. The sense of nationalism is fostered from an early age both in the environment and educational institution in building taxpayer awareness in paying tax. It means that a sense of nationalism is one of the motivations for influencer tax compliance. The third is a need for the administrative requirement for works matter. The emergence of requirements related to tax for works has become one of the most common reasons for taxpayer unintentional compliance behavior.

The imposition of the obligation for every Indonesian citizen to have a Taxpayer Identification Number (TIN) through several educational and financial institutions can affect influencers' intention to comply and report their income tax. In addition, as influencers perform a commercial business on social media, having a TIN is mandatory as their job is done online and electronically (Jamain, 2021). According to Article 2 of Law No. 28 of 2000, it is explained that an individual is required to have a TIN when subjective and objective requirements have been met. An influencer is identified as an individual taxpayer who must register for a TIN a month after their income exceeds the non-taxable income.

To increase influencers' tax compliance, it is necessary to hold updates obtained from influencers themselves regarding their perspective toward tax regulation. In addition, a specific regulation or tax design or system, as well as fair sanction, should be made, 
especially for influencers' commercial activity that will be taxed (Groulx \& McGregor, 2018; T. T. D. Nguyen et al., 2020; Radvan, 2021; Sekeroglu \& Bilgin, 2019). Through this process, it is expected that influencers may understand more and grow their sensitivity to the importance of paying tax from income received through social media platforms to increase the stability of the profession they pursue.

\section{Conclusion and Suggestion}

There are several reasons behind influencers' tax incompliance behaviors which are insufficient understanding about income tax, low trust level in the tax system, and unclear tax imposition and categorization mechanisms. Contrary, this study also finds out some reasons regarding influencer's tax compliance which are sufficient knowledge about tax, a high level of nationalism, and the emergence needs related to tax, such as for administrative requirements for work. In addition, regarding the rising number of influencers during the COVID-19 pandemic, the Indonesian Tax General Directorate has prepared strategies to identify new influencers who are eligible as taxpayer candidates. On the other hand, the growth of many influencers during the pandemic has also increased the public's sensitivity toward the use of social media and technology as income-earning platforms. The number of influencers is predicted to increase in the future, and it is expected that they can contribute to more government revenue from the tax. The government has also increased the intensity of their official Instagram account to spread awareness also to educate targeted profession, especially influencers and their audience. In terms of increasing the number of taxpayers, this study can be used as a tool to analyze what reasons behind their behavior.

This study was conducted carefully by applying scientific procedures. However, there are still several limitations in the data collection process, such as the struggle to find informants from influencers. Out of a hundred emails sent to prominent influencers, only thirteen influencers were willing to be informants due to their privacy concerns. Besides, influencers who become informants for this study also do other jobs, resulting in broad answers to their tax compliance behavior due to their diverse source of income. Moreover, due to the limited time duration provided by the influencers for the interview, then there is a possibility not to gather data as in-depth as expected. Further studies should conduct more number of informants with wider category influencers and a more comprehensive approach by using a quantitative method. An influencer who is famous in one particular category such as beauty, lifestyle, trading, and so on, may earn different amounts of income. 
The income tax compliance of social media influencers during COVID-19 pandemic: An exploratory study by Yeney Widya Prihatiningtias, Gracyella Natalie Putri Karo Karo

\section{References}

Alshira'h, A. F., Al-Shatnawi, H. M., Al-Okaily, M., Lutfi, A., \& Alshirah, M. H. (2021). Do public governance and patriotism matter? Sales tax compliance among small and medium enterprises in developing countries: Jordanian evidence. EuroMed Journal of Business, 16(4), 431-455. https://doi.org/10.1108/EMJB-01-2020-0004

Andreas, \& Savitri, E. (2015). The effect of tax socialization, tax knowledge, expediency of tax ID number and service quality on taxpayers compliance with taxpayers awareness as mediating variables. Social and Behavioral Sciences, 211, 163-169.

Anggadha, F., \& Rosdiana, H. (2020). Analysis of Efforts to Increase Income Taxes of Social Media Influencers in Endorsement Activities. Jurnal Administrasi Publik: Public Administration Journal, 10(2), 111-117. https://doi.org/10.31289/jap.v10i2.3094

Ardiansyah, F., \& Sarwoko, E. (2020). How social media marketing influences consumers purchase decision? A mediation analysis of brand awareness. JEMA: Jurnal Ilmiah $\begin{array}{lllll}\text { Bidang Akuntansi Dan } & \text { Manajemen, }\end{array}$ https://doi.org/10.31106/jema.v17i2.6916

Batrancea, L., Nichita, A., Olsen, J., Kogler, C., Kirchler, E., Hoelzl, E., Weiss, A., Torgler, B., Fooken, J., Fuller, J., Schaffner, M., Banuri, S., Hassanein, M., Alarcón-García, G., Aldemir, C., Apostol, O., Bank Weinberg, D., Batrancea, I., Belianin, A., ... Zukauskas, S. (2019). Trust and power as determinants of tax compliance across 44 nations. Journal of Economic Psychology, 74, 102191. https://doi.org/10.1016/j.joep.2019.102191

Beverland, M., \& Lindgreen, A. (2010). What makes a good case study? A positivist review of qualitative case research published in Industrial Marketing Management, 1971-2006. Industrial Marketing Management, 39(1), 56-63. https://doi.org/10.1016/j.indmarman.2008.09.005

Creswell, J. W. (2007). Qualitative Inquiry and Research Design (2nd ed.). SAGE Publisher, Inc.

De Neve, J.-E., Imbert, C., Spinnewijn, J., Tsankova, T., \& Luts, M. (2021). How to Improve Tax Compliance? Evidence from Population-Wide Experiments in Belgium. Journal of Political Economy, 129(5), 1425-1463. https://doi.org/10.1086/713096

Enyioko, N. C., \& Okwandu, G. A. (2019). Effect of Social Media Marketing on The Conversion Rate of Deposit Money Banks in Nigeria. JEMA: Jurnal Ilmiah Bidang Akuntansi Dan Manajemen, 16(1), 1. https://doi.org/10.31106/jema.v16i1.2141

Etienne, J. (2011). Compliance Theory: A Goal Framing Approach. Law \& Policy, 33(3), 
305-333. https://doi.org/10.1111/j.1467-9930.2011.00340.x

Faizal, S. M., Palil, M. R., Maelah, R., \& Ramli, R. (2017). Perception on justice, trust and tax compliance behavior in Malaysia. Kasetsart Journal of Social Sciences, 38(3), 226232. https://doi.org/10.1016/j.kjss.2016.10.003

Falya, D., \& Dirkareshza, R. (2021). Urgensi peraturan pajak dalam aktivitas endorsement yang dilakukan oleh influencer 'INSTAGRAM.' JURNAL USM LAW REVIEW, 4(2), 756. https://doi.org/10.26623/julr.v4i2.3962

Groulx, A., \& McGregor, C. (2018). A social media tax data warehouse to manage the underground economy. The 20th International Conference on High Performance Computing and Communications, 1599-1606.

Hajawiyah, A., Suryarini, T., Kiswanto, \& Tarmudji, T. (2021). Analysis of a tax amnesty's effectiveness in Indonesia. Journal of International Accounting, Auditing and Taxation, 44, 100415. https://doi.org/10.1016/j.intaccaudtax.2021.100415

Hofmann, E., Voracek, M., Bock, C., \& Kirchler, E. (2017). Tax compliance across sociodemographic categories: Meta-analyses of survey studies in 111 countries. Journal of Economic Psychology, 62, 63-71. https://doi.org/10.1016/j.joep.2017.06.005

Hunt, N. C., \& Iyer, G. S. (2018). The effect of tax position and personal norms: An analysis of taxpayer compliance decisions using paper and software. Advances in Accounting, 41, 1-6. https://doi.org/10.1016/j.adiac.2018.02.003

Hussain, W. (2020). Role of Social Media in COVID-19 Pandemic. The International Journal of Frontier Sciences, 4(2), 59-60. https://doi.org/10.37978/tijfs.v4i2.144

Jamain, T. H. (2021). Analisis Kesadaran Wajib Pajak Dalam Transaksi Ecommerce (Studi Kasus Wajib Pajak Orang Pribadi (WPOP) Yang Merupakan Pelaku E-Commerce Di Kota DKI Jakarta. Jurnal Industri Kreatif Dan Kewirausahaan, 2(2). https://doi.org/10.36441/kewirausahaan.v2i2.62

James, S., \& Alley, C. (2002). Tax compliance, self-assessment and tax administration. Journal of Finance and Management in Public Services, 2(2), 27-42.

Kaplan, A. M., \& Haenlein, M. (2010). Users of the world, unite! The challenges and opportunities of Social Media. Business Horizons, 53(1), 59-68. https://doi.org/10.1016/j.bushor.2009.09.003

Kemme, D. M., Parikh, B., \& Steigner, T. (2020). Tax Morale and International Tax Evasion. Journal of World Business, 55(3), 101052. https://doi.org/10.1016/j.jwb.2019.101052

Kemp, S. (2021). Digital 2021: Global Overview Report. DataReportal.Com. https://datareportal.com/reports/digital-2021-global-overview-report 
The income tax compliance of social media influencers during COVID-19 pandemic: An exploratory study by Yeney Widya Prihatiningtias, Gracyella Natalie Putri Karo Karo

Kirchler, E., Hoelzl, E., \& Wahl, I. (2008). Enforced versus voluntary tax compliance: The “slippery slope" framework. Journal of Economic Psychology, 29(2), 210-225. https://doi.org/10.1016/j.joep.2007.05.004

Krisna, D. (2020). The effect of religiosity, nationalism, perception, and taxation knowledge on taxpayer compliance (Empirical study on individual taxpayers of employees registered at KPP Pratama Pondok Aren period 2020). E-Proceeding of Management, 8 , 118.

Le, B., \& Moore, P. H. (2021). The effects of state ownership and tax rate cuts on accounting conservatism: evidence from Vietnam. Pacific Accounting Review, ahead-of-p(ahead-ofprint). https://doi.org/10.1108/PAR-12-2020-0209

Mascagni, G., Mengistu, A. T., \& Woldeyes, F. B. (2021). Can ICTs increase tax compliance? Evidence on taxpayer responses to technological innovation in Ethiopia. Journal of Economic Behavior \& Organization, 189, 172-193. https://doi.org/10.1016/j.jebo.2021.06.007

Memari, Z., Rezaei Pandari, A., \& Bemanzadeh, F. (2021). An interpretive structural model for factors affecting the tax compliance of professional athletes: a case study of football players. International Journal of Sports Marketing and Sponsorship, ahead-of-p(aheadof-print). https://doi.org/10.1108/IJSMS-03-2021-0077

Miles, M. B., \& Huberman, A. M. (1994). Qualitative Data Analysis: An Expended Sourcebook (2nd ed.). SAGE Publisher, Inc.

Mutia, S. P. T. (2014). Pengaruh Sanksi Perpajakan, Kesadaran Perpajakan, Pelayanan Fiskus, Dan Tingkat Pemahaman Terhadap Kepatuhan Wajib Pajak Orang Pribadi (Studi Empiris pada Wajib Pajak Orang Pribadi yang terdaftar di KPP Pratama Padang). Jurnal Akuntansi, 2(1).

Nguyen, L. T., Nguyen, A. H. V., Le, H. D., Le, A. H., \& Truong, T. T. V. (2020). The Factors Affecting Corporate Income Tax Non-Compliance: A Case Study in Vietnam. The Journal of Asian Finance, Economics and Business, 7(8), 103-115. https://doi.org/10.13106/jafeb.2020.vol7.no8.103

Nguyen, T. T. D., Pham, T. M. L., Le, T. T., Truong, T. H. L., \& Tran, M. D. (2020). Determinants Influencing Tax Compliance: The Case of Vietnam. The Journal of Asian Finance, Economics and 6usiness, 65-73. https://doi.org/10.13106/jafeb.2020.vol7.no2.65

Novikasari, S. R., Quang Ly, D., \& Gershaneck, K. (2021). Taxing Micro, Small and Medium Enterprises in Yogyakarta: Regulation and Compliance. BESTUUR, 9(1), 59. 
https://doi.org/10.20961/bestuur.v9i1.49184

Nugroho, A., Andini, R., \& Raharjo, K. (2016). Pengaruh kesadaran wajib pajak dan pengetahuan perpajakan wajib pajak terhadap kepatuhan wajib pajak dalam membayar pajak penghasilan (studi kasus pada KPP Semarang Candi). Journal Of Accounting, 2, 2.

Nurhaliza, S. (2020). Hai YouTuber! Sri Mulyani Minta Rutin Bayar Pajak. IDX CHannel. https://www.idxchannel.com/market-news/hai-youtuber-sri-mulyani-minta-rutin-bayarpajak

Owusu, G. M. Y., Bekoe, R. A., \& Mintah, R. (2021). Predictors of tax compliance intentions among self-employed individuals: the role of trust, perceived tax complexity and antecedent-based intervention strategies. Small Enterprise Research, 1-22. https://doi.org/10.1080/13215906.2021.1989622

Palil, M. R. (2010). Tax knowledge and tax compliance determinants in self assessment system in Malaysia. University of Birmingham.

Patton, M. Q. (1999). Enhancing the quality and credibility of qualitative analysis. Health Services Research, 34(5 Pt 2), 1189.

Piekkari, R., Welch, C., \& Paavilainen, E. (2009). The Case Study as Disciplinary Convention. Organizational Research Methods, 12(3), 567-589. https://doi.org/10.1177/1094428108319905

Pradana, A. H. (2020). Pajak Penghasilan Terhadap Endorsement Social Media Influencer Dalam Sistem Assessment [Universitas Airlangga]. http://repository.unair.ac.id/104045/

Punardi, A. (2019). Selebgram Sudah (seharusnya) Bayar Pajak. Direktorat Jenderal Pajak. https://pajak.go.id/artikel/selebgram-sudah-seharusnya-bayar-pajak

Radvan, M. (2021). Taxation of instagram influencers. UMCS in Lublin, 30(2), 339-356.

Risdiana, N., Utari, P., \& Satyawan, I. A. (2020). Gaining Voluntary Tax Compliance through Social Media Influencers: a Descriptive Analysis of the Meaning of Hashtag Usage\# PajakProfesi on Instagram Account of Directorate General of Taxes. ICSSED 2020: The Proceedings of the 4th International Conference of Social Science and Education, 177.

Roria, S., \& Sari, W. K. (2021). Tinjauan Pengenaan Pajak atas Aktivitas Endorsement oleh Selebgram di Indonesia. Jurnal SIKAP (Sistem Informasi, Keuangan, Auditing Dan Perpajakan), 5(1), 122. https://doi.org/10.32897/jsikap.v5i1.472

Sari, S. (2019). Literasi media pada generasi milenial di era digital. Profesional: Jurnal Komunikasi Dan Administrasi Publik, 6(2), 30-42. 
The income tax compliance of social media influencers during COVID-19 pandemic: An exploratory study by Yeney Widya Prihatiningtias, Gracyella Natalie Putri Karo Karo https://doi.org/10.37676/professional.v6i2.943

Sekaran, U., \& Bougie, R. (2019). Research methods for business: A skill building approach. John Wiley \& Sons, Inc.

Sekeroglu, S., \& Bilgin, S. (2019). Influencer Marketing and Taxation of Influencer in Turkey. In New Trends in Social Sciences, eds. H. Özüdogru, T. Çetin, H. Kara, Klaipeda (pp. 125-134).

Singh, V., \& Bhupalan, R. (2001). The Malaysian self assessment system of taxation issues and challenges. Scientific Research Publishing, Tax National, 12-17.

Suciu, P. (2020). History Of Influencer Marketing Predates Social Media By Centuries - But Is There Enough Transparency In The 21st Century? Forbes.Com. Forbes. https://www.forbes.com/sites/petersuciu/2020/12/07/history-of-influencer-marketingpredates-social-media-by-centuries--but-is-there-enough-transparency-in-the-21stcentury/?sh=2c5ddf6a $40 \mathrm{~d} 7$

Taing, H. B., \& Chang, Y. (2021). Determinants of Tax Compliance Intention: Focus on the Theory of Planned Behavior. International Journal of Public Administration, 44(1), 6273. https://doi.org/10.1080/01900692.2020.1728313

Tarjo, T., \& Kusumawati, I. (2006). Analisis Perilaku Wajib Pajak Orang Pribadi terhadap Pelaksanaan Self Assessment System: Suatu Studi di Bangkalan. Jurnal Akuntansi Dan Auditing Indonesia, 10(1), 101-120.

Taylor, D. G. (2020). Putting the "self" in selfies: how narcissism, envy and self-promotion motivate sharing of travel photos through social media. Journal of Travel \& Tourism Marketing, 37(1), 64-77. https://doi.org/10.1080/10548408.2020.1711847

Tjondro, E., Soegihono, A., Fernando, F., \& Wanandi, F. (2019). Intergenerational perception of tax audit and voluntary tax compliance. Business and Management Research, 103, 69-81.

Uly, Y. A. (2020). Banyak Influencer yang Tak Punya NPWP? Kompas.Com. https://money.kompas.com/read/2020/11/13/143700026/banyak-influencer-yang-takpunya-npwp-?page=all

Uzunoğlu, E., \& Misci Kip, S. (2014). Brand communication through digital influencers: Leveraging blogger engagement. International Journal of Information Management, 34(5), 592-602. https://doi.org/10.1016/j.ijinfomgt.2014.04.007

Wardani, D. K., \& Wati, E. (2018). Pengaruh Sosialisasi Perpajakan Terhadap Kepatuhan Wajib Pajak Dengan Pengetahuan Perpajakan Sebagai Variabel Intervening (Studi Pada Wajib Pajak Orang Pribadi Di KPP Pratama Kebumen). Nominal, Barometer Riset 
Akuntansi Dan Manajemen, 7(1). https://doi.org/10.21831/nominal.v7i1.19358

Wiederhold, B. K. (2020). Social Media Use During Social Distancing. Cyberpsychology, Behavior, and Social Networking, 23(5), 275-276. https://doi.org/10.1089/cyber.2020.29181.bkw

Williams, C. (2020). Evaluating Public Administration Approaches towards Tax NonCompliance in Europe. Administrative Sciences, $10(3), 43$. https://doi.org/10.3390/admsci10030043

Yin, R. K. (2012). Applications of Case Study Research (Vol. 3). SAGE Publisher, Inc. 